\title{
Influence of dexamethasone and surfactant in the vitality and lung function of preterm lambs born by cesarean section
}

\author{
[Influência da dexametasona e do surfactante na vitalidade e na função pulmonar de cordeiros \\ prematuros nascidos por cesariana eletiva] \\ F. Bovino ${ }^{1,2}$, D.S. Denadai ${ }^{3}$, L.G. Ávila ${ }^{1}$, M. Deschk ${ }^{1}$, P.S.P. Santos ${ }^{4}$, \\ F.L.F. Feitosa ${ }^{4}$, J.R. Peiró ${ }^{4}$, L.C.N. Mendes ${ }^{4}$ \\ ${ }^{1}$ Aluno de pós-graduação -Universidade Estadual Paulista (Unesp)- Faculdade de \\ Medicina Veterinária - Araçatuba, SP \\ ${ }^{2}$ Faculdade de Ciências Agrárias de Andradina - Fundação Educacional de Andradina (FCAA-FEA) - Andradina, SP \\ ${ }^{3}$ Aluno de graduação - Universidade Estadual Paulista (Unesp) - Faculdade de Medicina Veterinária, Araçatuba, SP \\ ${ }^{4}$ Universidade Estadual Paulista (Unesp) - Faculdade de Medicina Veterinária- Araçatuba, SP
}

\begin{abstract}
The aim of this study was to assess the vitality and lung function of preterm lambs. Twenty seven preterm lambs were divided in four groups. Group I ( $n=6)$ preterm lambs/ control; group II ( $n=9)$ lambs born to mothers that were treated with dexamethasone antepartum; group III $(n=6)$ lambs treated with surfactant; and group IV $(\mathrm{n}=6)$ lambs treated with surfactant and born to mothers that were treated with dexamethasone antepartum. The APGAR score was performed after birth $\left(\mathrm{T}_{0}\right)$ and 15 minutes later $\left(\mathrm{T}_{1 / 4}\right)$ to assess vitality. The vital signs, blood gas analysis, spirometry and capnometry were assessed immediately after birth and continued until 48 hours. Chest radiographs were performed at $T_{0}, T_{24}$ and $\mathrm{T}_{48}$. Significant rectal temperature interactions occurred at $\mathrm{T}_{1}$ and $\mathrm{T}_{6}$ depending on the type of treatment used. All animals showed low $\mathrm{pH}$ values, which were associated with high $\mathrm{pCO}_{2}$ values and $\mathrm{HCO}_{3}$ values that increased over time from immediately after birth to two days of age. Higher tidal volume values were observed at $T_{1 / 4}, T_{1}$ and $T_{24}$ when the animals were not treated with surfactant. Capnometry showed significant interactions between treatments at $\mathrm{T}_{0}$. Premature animals showed low vitality and impaired pulmonary function.
\end{abstract}

Keywords: lambs, neonatology, vitality, vital parameters

\section{RESUMO}

O objetivo do presente trabalho foi avaliar a vitalidade e a função pulmonar de cordeiros prematuros. Vinte e sete cordeiros foram divididos em quatro grupos: grupo I $(n=6)$, cordeiros prematuros/controle; grupo II $(n=9)$, cordeiros prematuros nascidos de mães tratadas com dexametasona antes do parto; grupo III $(n=6)$, cordeiros prematuros tratados com surfactante; e grupo IV $(n=6)$, cordeiros prematuros tratados com surfactante e nascidos de mães tratadas com dexametasona antes do parto. $O$ escore APGAR foi realizado após o nascimento $\left(T_{0}\right)$ e 15 minutos depois $\left(T_{1 / 4}\right)$. Os parâmetros vitais, hemogasometria, espirometria e capnometria foram avaliados após o nascimento até 48 horas. As radiografias torácicas foram realizadas em $T_{0}, T_{24}$ e $T_{48}$. Interações significativas de temperatura retal ocorreram em $T_{1}$ e $T_{6}$, dependendo do tipo de tratamento utilizado. Todos os animais apresentaram valores de pH baixos, que foram associados com altos valores de $\mathrm{pCO}_{2}$ e valores de $\mathrm{HCO}_{3}$ que aumentaram ao longo do tempo. Os maiores valores de volume corrente foram observados em $T_{1 / 4}, T_{1} e$ $T_{24}$, quando os animais não foram tratados com surfactante. A capnometria mostrou interações significativas entre tratamentos em $T_{0}$. Os animais prematuros apresentaram pouca vitalidade $e$ deficiência da função pulmonar.

Palavras-chave: cordeiro, neonatologia, vitalidade, parâmetros vitais

Recebido em 8 de novembro de 2017

Aceito em 28 de fevereiro de 2018

E-mail: ferbovino@yahoo.com.br 


\section{INTRODUCTION}

Lambs born before 138 days of gestation are considered preterm (Radostistset al., 2007, Edmondson et al., 2012).Lambing can be reliably induced in ewes after day 137 of gestation with dexamethasone (15 to $20 \mathrm{mg}$ IM), with dexamethasone, but better lamb survival rates may be expected if induction is initiated within 1 week of the expected due date or after day 142 of gestation (Edmondson et al., 2012).

Use the antepartum of dexamethasone in ewes has been shown to be effective in decreasing the mortality rate in premature lambs and improving the clinical condition of those animals (Avila et al., 2014).

The aim of this study was to assess the administration of dexamethasone in combination or not with surfactant intratracheal instillation to ewes antepartum (36 hours prior to delivery) and its effects on the vitality and lung function of preterm lambs born from elective c-section.

\section{MATERIALS AND METHODS}

The project was approved by the Animal Ethics Committee of Sao Paulo State University (Unesp), School of Veterinary Medicine, Araçatuba (Comitê de Ética no Uso de AnimaisdaUniversidadeEstadualPaulista, CEUA-UNESP), and it was registered under CEUA protocol number 959/2012. The following four experimental groups of crossbred Suffolk lambs born by elective C-sections performed at 137 days of gestation were formed: Group I: six preterm lambs; Group II: nine premature lambs born to mothers treated intramuscularly with 16mg of dexamethasone (Azium ${ }^{\circledR}$ - MSD Saúde Animal - Brazil) 36 hours before surgery (135 days); Group III: six preterm lambs treated with a single administration of surfactant (Survanta ${ }^{\circledR}$ - Abbott Laboratórios do BrasilLtda - Brazil) $(100 \mathrm{mg} / \mathrm{kg})$ by tracheal instillation immediately after birth; and Group IV: six preterm lambs treated with a single administration of surfactant and mothers that were treated intramuscularly with dexamethasone.

The ewes were kept on pasture, supplemented with corn silage and fed a commercial diet (Ration for adult sheep - GrupoPastofort Brazil) once a day during the majority of the gestation period. The ewes were placed in separated stalls at approximately 15 days before the expected date of delivery and kept until 60 days postpartum. All ewes were estrus synchronization protocol related by Avila et al., 2017. After 45 and 60 days from the last date of breeding abdominal ultrassound examination (Mindray DP 200 Vet Ultrasound device - DPS Equipamentos - Brazil) was performed for pregnancy confirmation and the surgery scheduled for 137 days of gestation.

A proximal paravertebral block with lidocaine hydrochloride (Xylestesin ${ }^{\circledR}$ Cristáliaprodutosquímicos e farmacêuticos LTDA - Brazil) and lumbosacral epidural anesthesia with morphine sulfate (Dimorf® Cristáliaprodutosquímicosfarmacêuticos LTDA Brazil) were performed on the ewes subjected to elective $\mathrm{C}$-sections. The same surgeon performed all the elective $\mathrm{C}$-sections in the right lateral decubitus position for left flank incision according to the method reported by Tibary and Van Metre (2004).

The assessment began immediately after birth and continued until 48 hours of life. The oral and nasal cavities were aspirated using an aspirator to remove as much liquid as possible before cutting the umbilical cord. The animals from groups treated with surfactant (III and IV) were intubated with 2.5 or 3.0 orotracheal tubes to administer the surfactant before cutting the umbilical cord. The surfactant dose was $100 \mathrm{mg} / \mathrm{kg}$ in a single administration, and the total volume was applied with the lamb placed in three different decubitus positions (right lateral, dorsal and left lateral) (Ueda et al., 1994). The animals from the other groups (I and II) were observed immediately after removal from the uterus to assess whether they showed spontaneous breathing movement. The animals that were not breathing were intubated, and assisted ventilation support using a neonatal bagvalve mask (Neonatal Ambu bag - valve masks Silicone manual resuscitator, complete with oxygen reservoir $-250 \mathrm{~mL}-$ Protec - Brazil)at a frequency of 30 strokes per minute was administered for the first 30 minutes of life.

The vital signs heart rate (HR), respiratory rate (RR) and rectal temperature (RT), which are associated with the capillary refill time (CRT) and eye mucous membrane color of the lambs, 
were assessed immediately after birth $\left(\mathrm{T}_{0}\right)$, at 15 minutes $\left(\mathrm{T}_{1 / 4}\right)$ and at one hour $\left(\mathrm{T}_{1}\right)$, six hours $\left(\mathrm{T}_{6}\right), 12$ hours $\left(\mathrm{T}_{12}\right), 24$ hours $\left(\mathrm{T}_{24}\right)$ and 48 hours after birth $\left(\mathrm{T}_{48}\right)$. The vitality assessment was performed using the Activity, Pulse, Grimace, Appearance, Respiration (APGAR) score at $\mathrm{T}_{0}$ and $\mathrm{T}_{1 / 4}$ (Feitosa and Benesi, 2014).

For all lambs, the first supply of colostrum was used for bottle-feeding with colostrum from a bovine colostrum bank that had been previously stored before the lambing period. Colostrum was administered using a nasogastric tube in lambs without a sucking reflex. After the surgery was observed if the ewe accepted or rejected the lambs. If the sheep rejected the lambs, they were raised as orphans.

The blood samples for blood gas analysis were collected by jugular venipuncture using a $25 \mathrm{x}$ 0.7 -mm hypodermic needle coupled to a plastic syringe with lithium heparin calcium (Drihep ${ }^{\mathrm{TM}}$ A-Line ${ }^{\mathrm{TM}}$, Becton Dickinson Company, Brazil) (80IU heparin, for a volume of $1.6 \mathrm{~mL}$ ) and performed within 15 minutes of collection.

The assessment of the hydrogen potential $(\mathrm{pH})$, carbon dioxide partial pressure $\left(\mathrm{pCO}_{2}\right)$, bicarbonate $\left(\mathrm{HCO}_{3}^{-}\right)$and base excess/deficit (BE/D) values was conducted in an electronic portable clinical analyzer (i-Stat ${ }^{\circledR}$ Portable Clinical Analyzer, Abbott Laboratories, Abbott Park, IL, USA) using specific cartridges (EG7+ Cartridge, Abbott Laboratories, USA) according to the manufacturer's instructions, and the analyzer was automatically calibrated before processing the samples. The device was also used to adjust the $\mathrm{pH}$ and $\mathrm{pCO}_{2}$ values according to the rectal temperature of each animal, which was measured with a digital clinical thermometer.

The radiographic examination was performed by placing the animals in the lateral decubitus position for lateral projection using a portable Xray device (Portable X-ray - Model Orange $1025 \mathrm{HF}$ - Oxson) and diagnostic X-ray films sized 24 x $30 \mathrm{~cm}$ (T-MAT G/RA, Kodak ${ }^{\circledR}$, Brazil) in metal cassettes (X-OMAT Regular Screens, Kodak Lanex, Brazil), which were developed by automatic processing (MX-2, Macrotec, Brazil). The lung was evaluated for the presence or absence of interstitial, alveolar and bronchial patterns. The radiographic assessment was only performed at $\mathrm{T}_{0}, \mathrm{~T}_{24}$ and $\mathrm{T}_{48}$.

Spirometry and capnometry were performed at all assessment times through direct readings with a monitor (Dixtal, mod. DX-2020 - Brazil) using a mask coupled to the pediatric flow sensor for 30 seconds. This sensor was coupled to the distal end of the endotracheal tube at the initial time periods when the animals were intubated.

The end tidal volume (TV) and respiratory minute volume (RMV) were assessed during the spirometry examinations. The end-tidal $\mathrm{CO}_{2}$ partial pressure $\left(\mathrm{EtCO}_{2}\right)$ was analyzed in the capnometry examination. All procedures (anesthesia, elective surgeries) and ratings (clinics, laboratory and radiological) were always carried out by the same people on the team.

The statistical analysis was performed using a completely randomized $2 \times 2$ factorial design based on the groups of lambs born to mothers that were and were not treated with dexamethasone and groups of lambs that were and were not treated with surfactants immediately after birth for the seven time periods.

The data were submitted to an analysis of variance with repeated measures, and the factorial design and means were compared using Tukey's test at a 5\% significance level. The data were tested regarding normality and homogeneity.

The variable BE did not present a normal distribution and was analyzed using the Friedman test to compare the time periods of each group, and Dunn's multiple comparisons test were performed.

The variables mucous membrane colors, CRT, APGAR, radiographic changes and mortality rate were analyzed using Fisher's exact test at each time period. The analyses were performed using the Statistical Analysis System software (SAS, 2011).

\section{RESULTS}

Most of the preterm lambs showed vitality ranging from moderate to low. However, no significant differences were observed between groups at each time period. 
The large number of lambs with moderate or low vitality affected the mortality rate, and all the lambs from group III died (Table 1). Animal death always occurred within 24 hours of life.

The CRT values ranged from one to two seconds, and no significant differences were observed between groups. The mucous membrane color ranged from rosy to reddish, and significant differences were observed between groups at $\mathrm{T}_{12}(\mathrm{P}=0.0204)$ and $\mathrm{T}_{24}(\mathrm{P}=0.0250)$.

Table 1. Number of preterm lambs in the first 48 hours of life (live or dead, and percentage) born from Cesarean section at 137 days (group I), after administration of dexamethasone (group II), treated with surfactant (group III) or treated with surfactant and born to ewes treated with dexamethasone (group IV)

\begin{tabular}{|c|c|c|c|c|c|c|c|c|c|c|}
\hline \multirow{3}{*}{ Time } & \multirow{3}{*}{ Mortality } & & & \multicolumn{6}{|c|}{ Groups } & \multirow{3}{*}{$\mathrm{P}^{*}$} \\
\hline & & \multicolumn{2}{|c|}{ I } & \multicolumn{2}{|c|}{ II } & \multicolumn{2}{|c|}{ III } & \multicolumn{2}{|c|}{ IV } & \\
\hline & & $\mathrm{n}$ & $\%$ & $\mathrm{n}$ & $\%$ & $\mathrm{n}$ & $\%$ & $\mathrm{n}$ & $\%$ & \\
\hline \multirow{2}{*}{$\mathrm{T}_{0}$} & Live & 6 & 100 & 9 & 100 & 6 & 100 & 6 & 100 & \multirow[b]{2}{*}{$\longrightarrow$} \\
\hline & Dead & 0 & 0.0 & 0 & 0.0 & 0 & 0.0 & 0 & 0.0 & \\
\hline \multirow{2}{*}{$\mathrm{T}_{24}$} & Live & 4 & 66.7 & 7 & 77.8 & 0 & 0.0 & 5 & 83.3 & \multirow{2}{*}{0.0083} \\
\hline & Dead & 2 & 33.3 & 2 & 22,2 & 6 & 100 & 1 & 16.7 & \\
\hline \multirow{2}{*}{$\mathrm{T}_{48}$} & Live & 4 & 66.7 & 7 & 77.8 & 0 & 0.0 & 5 & 83.3 & \multirow{2}{*}{0.0083} \\
\hline & Dead & 2 & 33.3 & 2 & 22.2 & 6 & 100 & 1 & 16.7 & \\
\hline
\end{tabular}

Fisher`sexacttest

No significant interaction between HR and RR occurred between the treatments. However, a significant difference in HR was assessed between groups with and without surfactant treatment, with the animals treated with surfactant showing lower values at $\mathrm{T}_{0}, \mathrm{~T}_{1 / 4}$ and $\mathrm{T}_{1}$. A significant difference was observed between the groups treated and not treated with maternal dexamethasone at $\mathrm{T}_{1 / 4}$ and $\mathrm{T}_{1}$, with the groups treated with dexamethasone showing higher HR.

Differences in RR between the groups born to mothers treated or not with dexamethasone were observed at $\mathrm{T}_{6}$ and $\mathrm{T}_{48}$, with the groups born to mothers treated with dexamethasone showing higher RR values.

However, low RR values were observed at $\mathrm{T}_{0}$, and they differed from the values at all other time periods for group II. The lowest values of group III were found at $\mathrm{T}_{0}$ and $\mathrm{T}_{1 / 4}$, and they were significantly lower than at $\mathrm{T}_{6}$. In turn, significant differences in RR occurred in group IV between $T_{0}$ and $T_{12}$ and between $T_{24}$ and $T_{48}$.

There was a significant interaction effect on the $\mathrm{RT}$ at $\mathrm{T}_{1}$ and $\mathrm{T}_{6}$ (Table 2) depending on the type of treatment used. The RT was higher without the use of surfactant when dexamethasone was not used. When the surfactant was used, the RT was significantly higher when using dexamethasone. Higher values were also observed at $\mathrm{T}_{6}$ and associated with the use of dexamethasone when surfactant was not used, and higher values were recorded with the concomitant use of dexamethasone and surfactant.

Higher temperature values occurred at $T_{1 / 4}, T_{12}$ and $\mathrm{T}_{24}$ when the surfactant was not used (Table 2). The animals showed lower values at $\mathrm{T}_{12}$ and $\mathrm{T}_{24}$ when dexamethasone was not used.

Significant interactions occurred between the treatments in relation to the $\mathrm{pH}\left(\mathrm{T}_{1 / 4}, \mathrm{~T}_{1}\right.$, and $\left.\mathrm{T}_{6}\right)$, pCO2 $\left(\mathrm{T}_{1 / 4}\right.$ and $\left.\mathrm{T}_{1}\right)$ and $\mathrm{HCO}_{3}^{-}\left(\mathrm{T}_{1}\right.$ and $\left.\mathrm{T}_{6}\right)$. The interactions related to $\mathrm{pH}$ (Table 3) between groups were similar at the three times. An interaction occurred at $\mathrm{T}_{1 / 4}$ and $\mathrm{T}_{1}$ when assessing $\mathrm{pCO}_{2}$ (Table 3), and higher $\mathrm{pCO}_{2}$ levels were detected in the absence of dexamethasone when using the surfactant. At $\mathrm{T}_{1}$, extremely high $\mathrm{pCO}_{2}$ levels were also found in association with the surfactant when dexamethasone was not used. 


\section{Bovino et al.}

Table 2. Mean \pm standard deviation $( \pm \mathrm{SD})$ on of the rectal temperature $\left(\mathrm{RT},{ }^{\circ} \mathrm{C}\right)$ of preterm lambs not treated or treated with surfactant (WITHOUT and WITH) and born to ewes that were not treated or treated with dexamethasone (WITHOUT and WITH)

\begin{tabular}{|c|c|c|c|c|c|}
\hline \multirow{2}{*}{ Variable } & \multirow{2}{*}{ Time } & \multirow{2}{*}{ Surfactant } & \multicolumn{2}{|c|}{ Dexamethasone } & \multirow{2}{*}{ Mean } \\
\hline & & & Without & With & \\
\hline \multirow{21}{*}{$\operatorname{Rt}\left({ }^{\circ} \mathrm{c}\right)$} & \multirow{3}{*}{ T0 } & Without & $38.6 \pm 1.2$ & $38.6 \pm 0.7$ & $38.6 \pm 0.9$ \\
\hline & & With & $38.3 \pm 0.9$ & $38.4 \pm 0.7$ & $38.3 \pm 0.7$ \\
\hline & & Mean & $38.4 \pm 1.0$ & $38.5 \pm 0.7$ & \\
\hline & \multirow{3}{*}{$\mathrm{T} 1 / 4$} & Without & $37.6 \pm 1.1$ & $36.6 \pm 0.7$ & $37.0 \pm 0.9 \mathrm{a}$ \\
\hline & & With & $36.0 \pm 0.8$ & $35.8 \pm 1.4$ & $35.9 \pm 1.1 \mathrm{~b}$ \\
\hline & & Mean & $36.7 \pm 1.2$ & $36.2 \pm 1.1$ & \\
\hline & \multirow{3}{*}{$\mathrm{T} 1$} & Without & $36.4 \pm 1.2 \mathrm{a}$ & $36.7 \pm 1.5$ & $36.5 \pm 1.3$ \\
\hline & & With & $33.0 \pm 0.7 \mathrm{bb}$ & $36.2 \pm 1.8 \mathrm{a}$ & $35.3 \pm 2.2$ \\
\hline & & Mean & $35.2 \pm 2.0$ & $36.5 \pm 1.6$ & \\
\hline & \multirow{3}{*}{ T6 } & Without & $38.0 \pm 0.4 \mathrm{ba}$ & $38.8 \pm 0.2 \mathrm{ab}$ & $38.5 \pm 0.5$ \\
\hline & & With & $36.4 \pm 0 \mathrm{bb}$ & $39.3 \pm 0.4$ aа & $38.8 \pm 1.2$ \\
\hline & & Mean & $37.7 \pm 0.8$ & $39.0 \pm 0.4$ & \\
\hline & \multirow{3}{*}{$\mathrm{T} 12$} & Without & $38.6 \pm 0.4$ & $39.2 \pm 0.2$ & $39.0 \pm 0.4 \mathrm{~b}$ \\
\hline & & With & & $39.7 \pm 0.2$ & $39.7 \pm 0.2 \mathrm{a}$ \\
\hline & & Mean & $38.6 \pm 0.4 \mathrm{~b}$ & $39.2 \pm 0.4 \mathrm{a}$ & \\
\hline & \multirow{3}{*}{$\mathrm{T} 24$} & Without & $38.7 \pm 0.1$ & $39.1 \pm 0.4$ & $38.9 \pm 0.4 \mathrm{~b}$ \\
\hline & & With & & $39.4 \pm 0.3$ & $39.4 \pm 0.3 \mathrm{a}$ \\
\hline & & Mean & $38.7 \pm 0.1 \mathrm{~b}$ & $39.2 \pm 0.2 \mathrm{a}$ & \\
\hline & \multirow{3}{*}{$\mathrm{T} 48$} & Without & $38.4 \pm 0.5$ & $38.9 \pm 0.7$ & $38.7 \pm 0.7$ \\
\hline & & With & & $39.9 \pm 0.4$ & $39.0 \pm 0.4$ \\
\hline & & Mean & $38.4 \pm 0.5$ & $38.9 \pm 0.6$ & \\
\hline
\end{tabular}

${ }^{\text {Aa }}$ Means followed by different capital letter (dexamethasone, without or with) and lower letter (surfactant, without or with) differ by Tukey's test $(\mathrm{P}<0.05)$

A $\mathrm{HCO}_{3}$ - interaction was observed at $\mathrm{T}_{1}$ and $\mathrm{T}_{6}$, and values below the reference values were found in the animals without dexamethasone treatment when surfactant was administered. Lower values below the reference values were also observed at $\mathrm{T}_{1}$ in association with the surfactant treatment when dexamethasone was not used. No significant differences were observed for the variable BE/D.

The analysis of spirometric values did not show a significant interaction between the treatments in relation to RMV and TV. However, higher and different $T V$ values were observed at $T_{1 / 4}, T_{1}$ and $\mathrm{T}_{24}$ when the animals were not treated with surfactant.
The capnometry readings showed a significant interaction between treatments at $\mathrm{T}_{0}$, and significantly higher values were observed when the surfactant was administered to the lambs without using dexamethasone. A difference was observed between groups with and without dexamethasone treatment at $\mathrm{T}_{6}$ and $\mathrm{T}_{48}$, with the group without corticosteroid treatment presenting higher values of $\mathrm{EtCO}_{2}$.

The radiographic lung changes indicated that statistically significant differences did not occur between the groups at each time period, most of the animals showed alterations, and groups III and IV showed $100 \%$ alterations from $\mathrm{T}_{0}$ until $\mathrm{T}_{48}$. 
Influence of dexamethasone...

Table 3. Mean \pm standard deviation $( \pm \mathrm{SD})$ of the hydrogen potential $(\mathrm{pH})$, carbon dioxide partial pressure (pCO2) and bicarbonate (HCO3) of the venous blood of preterm lambs not treated or treated with surfactant (WITHOUT and WITH) and born to ewes that were not treated or treated with dexamethasone (WITHOUT and WITH)

\begin{tabular}{|c|c|c|c|c|c|}
\hline \multirow{2}{*}{ Variable } & \multirow{2}{*}{ Time } & \multirow{2}{*}{ Surfactant } & \multicolumn{2}{|c|}{ Dexamethasone } & \multirow[b]{2}{*}{ Mean } \\
\hline & & & Without & With & \\
\hline \multirow{24}{*}{$\mathrm{pH}$} & \multirow[b]{2}{*}{ T0 } & Without & $7.098 \pm 0.152$ & $7.053 \pm 0.074$ & $7.071 \pm 0.109 \mathrm{a}$ \\
\hline & & With & $6.976 \pm 0.106$ & $6.957 \pm 0.034$ & $6.967 \pm 0.096 b$ \\
\hline & \multirow{3}{*}{$\mathrm{T} 1 / 4$} & Without & $7.002 \pm 0.185 \mathrm{a}$ & $6.973 \pm 0.162$ & $6.984 \pm 0.164$ \\
\hline & & With & $6.783 \pm 0.074 \mathrm{bb}$ & $7.004 \pm 0.034 \mathrm{a}$ & $6.894 \pm 0.131$ \\
\hline & & Mean & $6.883 \pm 0.172$ & $6.987 \pm 0.125$ & \\
\hline & $\mathrm{T} 1$ & Mean & $7.007 \pm 0.227$ & $7.118 \pm 0.084$ & \\
\hline & \multirow{3}{*}{ T6 } & Without & $7.255 \pm 0.013 \mathrm{a}$ & $7.305 \pm 0.051$ & $7.287 \pm 0.047$ \\
\hline & & With & $7.095 \pm 0.00 \mathrm{bb}$ & $7.254 \pm 0.056 \mathrm{a}$ & $7.227 \pm 0.082$ \\
\hline & & Mean & $7.223 \pm 0.073$ & $7.284 \pm 0.057$ & \\
\hline & \multirow{3}{*}{$\mathrm{T} 12$} & Without & $7.294 \pm 0.079$ & $7.357 \pm 0.039$ & $7.334 \pm 0.062$ \\
\hline & & With & & $7.348 \pm 0.047$ & $7.348 \pm 0.047$ \\
\hline & & Mean & $7.294 \pm 0.079$ & $7.353 \pm 0.041$ & \\
\hline & \multirow[t]{3}{*}{$\mathrm{T} 48$} & With & & $7.347 \pm 0.021$ & $7.347 \pm 0.021$ \\
\hline & & Mean & $7.390 \pm 0.019$ & $7.346 \pm 0.043$ & \\
\hline & & Without & $81.9 \pm 15.0$ & $90.0 \pm 13.3$ & $86.8 \pm 14.1 \mathrm{~b}$ \\
\hline & \multirow[t]{3}{*}{ T0 } & With & $100.0 \pm 16.8$ & $102.7 \pm 12.4$ & $101.4 \pm 14.2 \mathrm{a}$ \\
\hline & & Mean & $91.0 \pm 17.9$ & $95.1 \pm 14.1$ & \\
\hline & & Without & $92.9 \pm 36.6$ & $91.1 \pm 30.0$ & $91.8 \pm 31.2$ \\
\hline & $\mathrm{T} 1 / 4$ & With & $120.3 \pm 22.0 \mathrm{a}$ & $79.1 \pm 14.7 \mathrm{~b}$ & $99.7 \pm 27.9$ \\
\hline & & Mean & $107.8 \pm 31.4$ & $86.0 \pm 24.6$ & \\
\hline & & Without & $69.5 \pm 5.4 \mathrm{~b}$ & $69.4 \pm 7.0$ & $69.4 \pm 6.2$ \\
\hline & $\mathrm{T} 1$ & With & $102.1 \pm 17.1$ aa & $69.1 \pm 4.4 \mathrm{~b}$ & $78.5 \pm 17.9$ \\
\hline & & Mean & $80.3 \pm 19.0$ & $69.3 \pm 5.8$ & \\
\hline & & Without & $55.1 \pm 2.9$ & $56.3 \pm 6.7$ & $55.9 \pm 5.5$ \\
\hline $\mathrm{pCO}_{2}$ & T6 & With & $65.1 \pm 0.0$ & $61.2 \pm 4.7$ & $61.8 \pm 4.5$ \\
\hline & & Mean & $55.9 \pm 5.5$ & $57.1 \pm 7.0$ & \\
\hline & & Without & $24.6 \pm 3.8$ & $24.6 \pm 6.4$ & $24.6 \pm 2.5$ \\
\hline & T0 & With & $22.9 \pm 1.9$ & $22.4 \pm 4.4$ & $22.6 \pm 3.2$ \\
\hline & & Mean & $23.7 \pm 3.0$ & $23.7 \pm 3.0$ & \\
\hline & & Without & $22.0 \pm 4.2$ & $20.5 \pm 2.4$ & $21.1 \pm 3.1$ \\
\hline & $\mathrm{T} 1 / 4$ & With & $18.0 \pm 2.0$ & $20.1 \pm 3.8$ & $19.1 \pm 3.1$ \\
\hline & & Mean & $19.8 \pm 3.6$ & $20.3 \pm 2.9$ & \\
\hline & & Without & $24.1 \pm 3.9 \mathrm{a}$ & $21.9 \pm 3.2$ & $22.7 \pm 3.4$ \\
\hline & $\mathrm{T} 1$ & With & $14.7 \pm 0.0 \mathrm{bb}$ & $23.5 \pm 3.8 \mathrm{a}$ & $21.0 \pm 5.3$ \\
\hline & & Mean & $21.0 \pm 5.7$ & $22.5 \pm 3.4$ & \\
\hline & & Without & $24.3 \pm 1.6$ & $25.7 \pm 2.7$ & $25.2 \pm 2.4$ \\
\hline $\mathrm{HCO}_{3}$ & T6 & With & $20.2 \pm 0 \mathrm{~b}$ & $26.5 \pm 3.5 \mathrm{a}$ & $25.5 \pm 4.0$ \\
\hline & & Mean & $23.5 \pm 2.3$ & $26.0 \pm 2.9$ & \\
\hline & & Without & $25.2 \pm 1.6$ & $29.2 \pm 1.7$ & $27.7 \pm 2.6$ \\
\hline & $\mathrm{T} 12$ & With & & $29.1 \pm 3.8$ & $29.1 \pm 3.8$ \\
\hline & & Mean & $25.2 \pm 2.3 \mathrm{~b}$ & $29.2 \pm 2.6 \mathrm{a}$ & \\
\hline & & Without & $29.3 \pm 2.1$ & $31.3 \pm 2.2$ & $30.5 \pm 2.3$ \\
\hline & $\mathrm{T} 24$ & With & & $31.3 \pm 3.4$ & $31.3 \pm 3.4$ \\
\hline & & Mean & $29.3 \pm 2.1$ & $31.3 \pm 2.6$ & \\
\hline & & Without & $33.3 \pm 2.0$ & $30.2 \pm 3.7$ & $31.3 \pm 3.3$ \\
\hline & $\mathrm{T} 48$ & With & & $30.8 \pm 1.6$ & $30.8 \pm 1.6$ \\
\hline & & Mean & $33.3 \pm 2.0$ & $30.4 \pm 2.9$ & \\
\hline
\end{tabular}

${ }^{\text {Aa }}$ Means followed by different capital letter (dexamethasone. without or with) and lower letter (surfactant. without or with) differ by Tukey's test $(\mathrm{P}<0.05)$ 


\section{DISCUSSION}

The identification of low-APGAR-score lambs at birth suggested that additional care is required (Vannucchiet al., 2012). The vitality findings are similar to those of Silva (2012), who also found lower APGAR values in animals treated only once with surfactant immediately at birth than in animals treated with other protocols or only with ventilation.

The immaturity of premature lambs is indicated by low APGAR scores, and $93.75 \%$ (Bovinoet al., 2014), 86.67\% (Avila et al., 2014) and $72.5 \%$ (Dutra and Banchero, 2011) of lambs born vaginally showed good vitality at birth.

A study of four different treatments with porcine-derived lung surfactant and manual ventilation in preterm lambs reported a low survival rate, and the highest rate of $40 \%(2 / 5)$ was found in animals that were not treated with surfactant, whereas all animals from the group treated after birth with a dose of surfactant survived for an average of 2.86 hours (Silva, 2012).

The antepartum use of dexamethasone in ewes effectively decreased the mortality rate in preterm lambs based on the improved clinical condition (Avila et al., 2014); however, statistically significant differences in the APGAR score, vital signs and mortality rates were not observed between the groups treated and not treated with dexamethasone. Notwithstanding, the lambs whose mothers were treated with dexamethasone antepartum had increased viability at birth and less difficulty initiating breathing movements, and they required less assistance after birth.

The HR values observed in the present study were lower than those reported for full-term lambs in the first three time periods (Terra, 2009; Vannucchiet al., 2012, Avila et al., 2014, Bovinoet al., 2014) and for preterm lambs, especially compared with the groups treated with surfactant at $\mathrm{T}_{0}, \mathrm{~T}_{1 / 4}$ and $\mathrm{T}_{1}$ (Silva, 2012; Avila et al., 2014). These values increased after a onehour period and remained similar to values reported for full-term lambs (Terra, 2009; Vannucchiet al., 2012, Avila et al., 2014, Bovinoet al., 2014). Immediately after the birth, lambs have low systolic volumes, and the heart must pump blood at a higher systolic rate into the vascular system that shows high elastic and peripheral resistance (Piccioneet al., 2006).

The low RR values were similar to the ones found by Ávila et al. (2014) for groups of preterm animals that were treated or not treated with dexamethasone. The lower values at birth resulted from the difficulty of preterm animals to initiate breathing movements, which are responsible for ventilation initiation and the establishment of functional residual capacity (Piccioneet al., 2007). It should be emphasized that no difference occurred between groups in the initial time periods, which was most likely because the animals with no spontaneous breathing movements were ventilated with bagvalve masks for 30 minutes at a frequency of 30 strokes per minute.

The lowest RT values were found at the initial times $\left(T_{1 / 4}\right.$ and $\left.T_{1}\right)$ in all groups and over time. The thermoregulatory capacity of lambs was limited and depended on the glycogen stores and oxidative action of brown adipose tissue. Fullterm lambs do not show such low birth temperatures, which may be explained by their maturity (Piccioneet al., 2006).

The lambs from all groups showed $\mathrm{pH}$ values below the physiological values for adult sheep (pH 7.35 - 7.50) (Carlson and Bruss, 2008) from immediately after birth to $\mathrm{T}_{6}$. High $\mathrm{pCO}_{2}$ values and $\mathrm{HCO}_{3}{ }^{-}$values that increased over time were assessed concurrently with the low $\mathrm{pH}$ values. The preterm newborns showed more intense respiratory acidosis symptoms at both initial time periods $\left(\mathrm{T}_{0}\right.$ and $\left.\mathrm{T}_{1 / 4}\right)$ that persisted until two days of life. However, the $\mathrm{pCO}_{2}$ values decreased and $\mathrm{pH}$ values increased, which is inconsistent with the results of Feitosaet al. (2017), who suggested that 24 hours was sufficient to stabilize the acidbase balance of full-term and preterm lambs. The birth $\mathrm{HCO}_{3}{ }^{-}$values fell within the range reported by Carlson and Bruss (2008); however, these values increased at 48 hours of life, which was also observed by Feitosaet al.(2017), in preterm lambs.

Respiratory acidosis symptoms suggest $\mathrm{CO}_{2}$ accumulation in the bloodstream because of the decreased alveolar ventilation, which initially leads to decreased $\mathrm{O}_{2}$ levels and then to increased $\mathrm{CO}_{2}$ pressure. Any dysfunction 
affecting ventilation, including prior respiratory obstruction, pneumonia, and pneumothorax, may cause respiratory acidosis (Carlson and Bruss, 2008). The $\mathrm{pCO}_{2}$ recorded in the first 48 hours of life remained higher than those reported by Carlson and Bruss (2008) ( $\mathrm{pCO}_{2}: 37$ $46 \mathrm{mmHg}) \cdot \mathrm{CO}_{2}$ removal under a reduced lung capacity (hypoventilation) does not occur at the same ratio of production. Consequently, an increase in blood $\mathrm{CO}_{2}$ levels occurs, and this $\mathrm{CO}_{2}$ retention may lead to an increased concentration of carbonic acid, which can lower the blood $\mathrm{pH}$ and increase $\mathrm{HCO}_{3}{ }^{-}$concentrations (Piccioneet al., 2006; Carlson and Bruss, 2008).

The interactions related to $\mathrm{pH}$ (Table 5) between groups were similar at the three time periods. Lower values were found when the surfactant was used without concomitant administration of dexamethasone, and lower $\mathrm{pH}$ values were found when instilling surfactant without the use of dexamethasone. These results indicate that the surfactant should be used in combination with dexamethasone or the surfactant should not be used when dexamethasone is not used.

The combined analysis of the $\mathrm{pH}$ and $\mathrm{pCO}_{2}$ interactions showed that they perform similarly and virtually at the same time periods, which indicates that the use of surfactant is dependent on the use of dexamethasone because all the animals that were only treated with surfactant died (Table 2) and surfactant treatment is not recommended when dexamethasone has not been administered.

A significant increase in TV only occurred in group IV. The TV of an adult sheep ranges from 10 to $20 \mathrm{~mL} / \mathrm{kg}$ (Mc Donell and Kerr, 2007). The lambs from groups I and II showed values within the normal range during the first 48 hours of life. Conversely, those treated with surfactant (group III and IV) showed the lowest values at birth and presented a gradual increase until 48 hours.

The values $\left(\mathrm{EtCO}_{2}\right)$ recorded in newborns were below the normal range $(35-45 \mathrm{mmHg})$ except at $\mathrm{T}_{0}$ in group $\mathrm{IV}$, which presented values within the normal range, and in group III, which presented extremely high values (McDonell and Kerr, 2007). Values below the normal range indicate that these lambs were experiencing hypoventilation, which may have resulted from inadequate alveolar ventilation or atelectasis
(Mazan, 2006). Therefore, the failure to correct the respiratory acidosis, which persisted until 48 hours of life, became even more evident. Thus, high $\mathrm{pCO}_{2}$ values may be associated with low $\mathrm{EtCO}_{2}$ values, which indicates that gas exchanges are compromised because of the reduced release of $\mathrm{CO}_{2}$.

Capnometry can indirectly express the pulmonary circulation status and $\mathrm{CO}_{2}$ supply. Low cardiac output and pulmonary embolism (air, amniotic fluid and thromboembolism) decrease the perfusion of alveolar segments, which therefore do not participate in gas exchanges (Amaralet al., 1992).

At 48 hours of life, three animals in group I showed radiographic changes with an alveolar pattern, and six animals in group II showed radiographic changes, including four with an alveolar pattern, one with a bronchial pattern and one with an interstitial, bronchial and alveolar pattern. Conversely, three lambs in group IV showed interstitial and alveolar patterns and two showed interstitial, alveolar and bronchial patterns, whereas all animals from group III died within 24 hours of life and showed pleural effusion at $\mathrm{T}_{0}$.

The 48-hour period was insufficient for these lambs to absorb all the fluid present in the lungs and to no longer present radiographic changes. Healthy foals show lungs without radiographic changes at six hours cited by Kutasiet al. (2009), whereas full-term lambs born from C-section require from one to four hours to absorb all the liquid present in the lungs (Fletcher et al., 1970).

Thus, the combined analysis of blood gas, spirometric and capnometric values and radiographic changes indicated severely compromised lungs in the premature lambs, especially those treated with surfactant, which presented greater difficulty eliminating $\mathrm{CO}_{2}$, indicating that gas exchange was not adequately performed in those animals. It is noteworthy that the surfactant compound has an extremely high cost and low concentration, which requires the use of large volumes per animal. Thus, the use of surfactant in livestock farming becomes an economically unviable practice because of the cost relative to the animal weight. 


\section{CONCLUSION}

Preterm lambs (137 days) born from elective Csection conclusively showed low vitality and lung function impairment that was not cured within 48 hours. The use of surfactant should be performed in combination with antepartum maternal dexamethasone administration, and surfactant should not be used in lambs whose mothers were not subjected to antepartum dexamethasone treatment. Treatment with a single dose of surfactant $(100 \mathrm{mg} / \mathrm{kg})$ by tracheal instillation should never be adopted. It is noteworthy that the spirometric values reported here are the first reported for this species at this age.

\section{ACKNOWLEDGMENTS}

This work was supported by the FAPESP (Fundação de Amparo à Pesquisa do Estado de São Paulo) to provide a financial support $\left(\mathrm{n}^{\circ}\right.$. 2011/18810-3); Bovino was supported by a $\mathrm{PhD}$ scholarship $\left(\mathrm{n}^{\circ}\right.$. 2011/18814-9); Denadai was supported by a student scholarship ( ${ }^{\circ}$. 2012/22897-0).

\section{REFERENCES}

AMARAL, J.L.G.; FERREIRA, A.C.P.; FEREZ, D.; GERETTO, P. Monitorização da respiração: oximetria e capnografia. Rev. Bras. Anestesiol., v.1, p.51-58, 1992.

AVILA, L.G.; BOVINO, F.; CAMARGO, D.G. et al. Aplicação materna de glicocorticoide nos parâmetros vitais de cordeiros nascidos a termo e prematuros. Cienc. Rural, v.6, p.1106-1112, 2014.

BOVINO, F.; CAMARGO, D.G.; ARAÚJO, M.A. et al. Avaliação da vitalidade de cordeiros nascidos de parto normal e de cesarianas. Pesqui. Vet. Bras., v.34, p.11-16, 2014.

CARLSON, G.P.; BRUSS, M.L. Fluid, electrolyte and acid-base balance. In: KANEKO, J.J.; HARVEY, J.W.; BRUSS, M.L. (Eds.). Clinical biochemistry of domestic animal. 6.ed. Burlington: Elsevier, 2008. p.529-569.

DUTRA, F.; BANCHERO, G. Polwarth and Texel ewe parturition duration and its association with lamb birth asphyxia. J. Anim. Sci., v.89, p.3069-3078, 2011.

EDMONDSON, M.A.; ROBERTS, J.F.; BAIRD, S.B.; PUGH, D.G. Theriogenology of sheep and goats. In: PUGH, D.G.; BAIRD, A.N. (Eds.). Sheep and goats medicine., 2.ed. Missouri: Elsevier, 2012. p.150-230.

FEITOSA, F.L.F.; ÁVILA, L.G.; BOVINO, F. et al. Efeitos da corticoterapia materna nos valores hemogasométricos de cordeiros nascidos a termo e prematuros. Pesqui. Vet. Bras. v.37, p.521-525, 2017.
FEITOSA, F.L.F.; BENESI, F.J. Semiologia de recémnascidos ruminantes e equideos. In: FEITOSA, F.L.F. (Ed.). Semiologia veterinária: a arte do diagnóstico. 4.ed. São Paulo: Roca, 2014. p.69-97.

FLETCHER, B.D.; SACHS, B.F.; KOTAS, R.V. Radiologic demonstration of postnatal liquid in the lungs of newborn lambs. Pediatrics, v.46, p.252-258, 1970.

KUTASI, O.; HORVATH, A.; HARNOS, A.; SZENCI, O. Radiographic assessment of pulmonary fluid clearance in healthy neonatal foals. Vet. Radiol. Ultrasound, v.50, p.584-588, 2009.

MAZAN, M.R. Noninfectious respiratory problems. In: PARADIS, M.R. (Ed.). Equine neonatal medicine: a casa-based approach. Philadelphia: Elsevier, 2006. p.135-148.

MC DONELL, W.N.; KERR, C.L. Respiratory system. In: TRANQUILLI, W.J.; THURMON, J.C.; GRIMM, K.A. (Eds.). Lumb\& Jones' veterinary anesthesia and analgesia. 4.ed. Iowa: Blackwell Publishing, 2007. p.117151.

PICCIONE, G.; BORRUSO, M.; FAZIO, F.; GIANNETTO, C.; CAOLA, G. Physiological parameters in lambs during the first 30 days postpartum. Small Ruminant Res., v.72, p.57-60, 2007.

PICCIONE, G.; COSTA, A.; BERTOLUCCI, C. et al.Small Ruminant Res., v.63, p.304-308, 2006.

RADOSTITS, O. M.; GAY, C. C.; HINCHCLIFF, K. W.; CONSTABLE, P. D. Veterinary medicine: a textbook of the diseases of cattle, horses, sheep, pigs and goats.10.ed. Philadelphia: ElsevierSaunders, 2007, 2156 p.

SILVA, L.C.G. Aplicação preventiva do surfactante porcino (Instituto Butantã) intra-traqueal no desempenho clínico e pulmonar de neonatos ovinos prematuros. 2012. Tese (Doutorado em Medicina Veterinária) - Faculdade de Medicina Veterinária e Zootecnia, Universidade de São Paulo, São Paulo, SP.

STATISTICAL analysis system. Version 9.3. Cary: SAS Institute, 2011.

TERRA, R.L. Ruminant history, physical examination and records. In: SMITH, B.P. (Ed.). Large animal internal medicine.4.ed. MosbyElsevier, 2009. p.3-14.

TIBARY, A.; VAN METRE, D. Surgery of the sheep and goat reproductive system and urinary tract. In: FUBINI, S.L.; DUCHARME, N.G. (Eds.). Farm animal surgery. St. Louis: Saunders, 2004, p.527-547.

UEDA, T.; IKEGAMI, M.; RIDER, E.D.; JOBE, A.H. Distribuition of surfactant and ventilation in surfactanttreatedpretemlambs. J. Appl. Physiol., v.76 p.45-55, 1994.

VANNUCCHI, C.I.; RODRIGUES, J.A.; SILVA, L.C.G.; LÚCIO, C.F.; VEIGA, G.A.L. A clinical and hemogasometricsurvey of neonatal lambs. Small Ruminant Res., v.108, p.107-112, 2012. 